\section{Elevated serum tumour necrosis factor- alpha levels can contribute to the insulin resistance in Type II (non-insulin-dependent) diabetes and in obesity}

\begin{abstract}
Dear Sir,
Tumour necrosis factor alpha (TNF- $\alpha)$ may play a role in the pathophysiology of obesity and also in the obesity-diabetes link [1]. The overexpression of the cytokine has been demonstrated in the adipose tissue of different rodent genetic models of obesity [2]. This overexpression of TNF- $\alpha$ led to the downregulation of the signal transduction of insulin receptor via the increased serin phosphorilation of the insulin receptor substrate (IRS)-1 turning it to an inhibitor of the receptor [3], although a contradictory observation has also been published [4]. Moreover, TNF- $\alpha$ also downregulates several genes in adipocytes, e.g. GLUT-4, lipoprotein lipase [2, 4] and adipsin [2, 4]. In TNF- $\alpha$ deficient obese mice the GLUT- 4 protein level was significantly higher only in the muscle tissue [5]. Targeted mutations in the genes of TNF- $\alpha$ and the two TNF-receptors resulted in an improved insulin sensitivity in animal models of obesity [5, 6]. According to these observations the role of TNF- $\alpha$ can be raised in insulin resistance and hyperinsulinaemia. In a follow-up study we have investigated serum TNF$\alpha$ bioactivity in Type II (non-insulin-dependent) diabetes mellitus and obesity.

We studied 59 (male/female 32/27, age $\overline{\mathrm{X}} \pm$ SE: $62 \pm 3$ years, BMI: $32.2 \pm 3.1 \mathrm{~kg} / \mathrm{m}^{2}$ ) patients with Type II diabetes (classification according to clinical data and C-peptide levels), 28 (10/ $18,49 \pm 4$ years, $39.5 \pm 3.0 \mathrm{~kg} / \mathrm{m}^{2}$ ) with a simple, android type obesity and $35\left(19 / 16,59 \pm 5\right.$ years, $\left.25.4 \pm 2.4 \mathrm{~kg} / \mathrm{m}^{2}\right)$ matched healthy control subjects for twelve months. Blood samples were taken at intervals of 8 weeks - six times per patients for measuring serum basal C-peptide and glucagon levels and TNF- $\alpha$ bioactivity.

C-peptide and glucagon levels were measured by commercial RIA kit-s (Serono, Italy, normal values for basal serum C-
\end{abstract}

Corresponding author: G. Winkler MD, PhD, Department of Internal Medicine II., St. John's Hospital Budapest, H-1125 Diósárok u. 1., Hungary
Table 1. Serum TNF- $\alpha$-, basal C-peptide and basal glucagon levels in Type II diabetic patients, obese persons and control subjects

\begin{tabular}{lcll}
\hline & $\begin{array}{l}\text { Type II dia- } \\
\text { betic patients }\end{array}$ & $\begin{array}{l}\text { Obese } \\
\text { persons }\end{array}$ & $\begin{array}{l}\text { Control } \\
\text { subjects }\end{array}$ \\
\hline $\begin{array}{l}\text { se-TNF- } \alpha \text { concentrations } \\
(\overline{\mathrm{X}} \pm \mathrm{SE}, \mathrm{pg} / \mathrm{ml})\end{array}$ & $90.0 \pm 10.0^{\mathrm{a}}$ & $78.0 \pm 12.0^{\mathrm{a}}$ & $22.0 \pm 8.0$ \\
$\begin{array}{l}\text { Basal se-C peptide level } \\
(\overline{\mathrm{X}} \pm \mathrm{SE}, \mathrm{ng} / \mathrm{ml})\end{array}$ & $1.8 \pm 0.4^{\mathrm{a}}$ & $1.3 \pm 0.4^{\mathrm{a}}$ & $0.6 \pm 0.1$ \\
$\begin{array}{l}\text { Basal se-glucagon level } \\
(\overline{\mathrm{X}} \pm \mathrm{SE}, \mathrm{pg} / \mathrm{ml})\end{array}$ & $105.4 \pm 17.3$ & $84.0 \pm 14.0$ & $65.6 \pm 12.7$ \\
\hline
\end{tabular}

$\overline{\mathrm{a}} \mathrm{p}<0.01$ as compared with control subjects (Student's $t$-test). Values are means of six different measurements

peptide levels $0.66-2.50 \mathrm{ng} / \mathrm{ml}$ [0.22-0.83 nmol/1], for basal glucagon levels $60-200 \mathrm{pg} / \mathrm{ml}$ [16.8-56.0 pmol/1]) and serum TNF$\alpha$ bioactivity by applying the L929 (ATCC) cell cytotoxicity bioassay [7]. Recombinant human TNF- $\alpha$ (Sigma, St. Louis, MS, USA) was used as a standard (concentration range: 0.625 $\mathrm{pg} / \mathrm{ml}-1.562 \mathrm{ng} / \mathrm{ml}$ ). Serum TNF- $\alpha$ bioactivity was expressed in $\mathrm{pg} / \mathrm{ml}$, calculated according to the bioactivity of the standard curve. Monoclonal neutralizing TNF- $\alpha$ and $-\beta$ mouse immunglobulins (Boehringer $\mathrm{GmbH}$, Mannheim, Germany) were used to detect the TNF- $\alpha$ bioactivity in the samples.

Significantly elevated serum TNF- $\alpha$ bioactivity and basal serum C-peptide levels were detected in both, the Type II diabetic and obese patients groups as compared with the control subjects. The values are means of six different measurements during the observation period. (Table 1). In $85 \%$ of the cases the individual serum TNF- $\alpha$ bioactivity in Type II diabetic and obese patients have been found to be above $45 \mathrm{pg} / \mathrm{ml}$ $(\overline{\mathrm{X}}+2 \mathrm{SD}$ value of the controls). The individual concentrations showed an approximately $40 \%$ difference evaluating the six measurements. No significant differences were observed between the means of the six consecutive measurements.

We could not measure any significant difference between males and females, or in different age groups (30-39, 40-49, $50-59,60-69$ and above 70 years), either in control subjects or in patients.

We could calculate a significantly positive linear correlation $(p<0.01)$ between the elevated basal serum C-peptide levels and the higher TNF- $\alpha$ bioactivity in both, the Type II diabetic 
$(r=0.56)$ and obese patient groups $(r=0.54)$. This positive correlation was also detectable between the patients BMI values and TNF- $\alpha$ activities in both patient groups (Type II diabetic patients $r=0.60$, obese patients $r=0.58$ ), and between basal serum C-peptide and BMI values (Type II diabetic patients $r=0.50$, obese patients $r=0.40, \mathrm{p}<0.05)$. We could not detect any correlation between serum TNF- $\alpha$ bioactivity and basal glucagon levels, nor between the BMI values and basal glucagon concentrations.

Contradictory results exist concerning circulating TNF- $\alpha$ levels in Type II diabetic patients. Elevated immunological concentrations were found only in males with Type II diabetes as compared with control subjects. In this study significantly elevated serum TNF- $\alpha$ levels were measured in healthy females as compared with males [8]. In the offsprings of Type II diabetic patients no correlations could be detected between immunological serum or plasma TNF- $\alpha$ concentrations and insulin sensitivity [9]. On the other hand, the $55 \mathrm{kDa}$ soluble TNF- $\alpha$ receptor level showed a strong positive association with the BMI, serum insulin level and leptin concentration in young healthy men and Type II diabetic patients [10].

In summary our observations suggest that elevated TNF- $\alpha$ bioactivity may be able to contribute to the insulin resistance in Type II diabetes and obesity. Further studies are necessary to clarify whether the elevated TNF- $\alpha$ levels are the cause or consequence in these pathophysiological conditions.

Yours sincerely,

G. Winkler, F. Salamon, D. Salamon, G. Speer, K. Simon and K. Cseh

\section{References}

1. Hotamisligil GS, Spiegelman BM (1994) Tumor necrosis factor- $\alpha$ : a key component of the obesity-diabetes link. Diabetes 43: 1271-1278
2. Hotamisligil GS, Shargill NS, Spiegelman BM (1993) Adipose expression of tumor necrosis factor-alpha: direct role in obesity linked insulin resistance. Science 259: 87-91

3. Hotamisligil GS, Peraldi P, Budaváry A, Ellis R, Wite MF, Spiegelman BM (1996) IRS-1-mediated inhibition of insulin receptor tyrosine kinase activity in TNF- $\alpha$ - and obesity-induced insulin resistance. Science 271: 665-668

4. Stephens JM, Lee J, Pilch PF (1997) Tumor necrosis factoralfa induced insulin resistance in 3T3-L1 adipocytes is accompanied by a loss of insulin receptor substrate- 1 and GLUT-4 expression without a loss of insulin receptor-mediated signal transduction. J Biol Chem 272: 971-976

5. Uysal KT, Wiesbrock SM, Marino MW, Hotamisligil GS (1997) Protection from obesity-induced insulin resistance in mice lacking TNF- $\alpha$ function. Nature 389: 610-614

6. Ventre J, Doebber T, Wu M et al. (1997) Targeted disruption of the tumor necrosis factor- $\alpha$ gene. Metabolic consequences in obese and nonobese mice. Diabetes 46: 1526-1531

7. Cseh K, Beutler B (1989) Alternative cleavage of the cachectin/tumor necrosis factor propeptide results in a larger inactive form of secreted protein. J Biol Chem 264: 16256-16260

8. Pfeiffer A, Janott J, Möhlig M et al. (1997) Circulating tumor necrosis factor $\alpha$ is elevated in male but not in female patients with Type II diabetes mellitus. Horm Metab Res 29: 111-114

9. Kellerer M, Rett K, Renn W, Groop L, Häring HU (1996) Circulating TNF-alpha and leptin levels in offsprings of NIDDM patients do not correlate to individual insulin sensitivity. Horm Metab Res 28: 737-743

10. Mantzoros CS, Moschos S, Avramopoulos I et al. (1997) Leptin concentrations in relation to body mass index and the tumor necrosis factor- $\alpha$ system in humans. J Clin Endocrinol Metab 82: 3408-3413 
